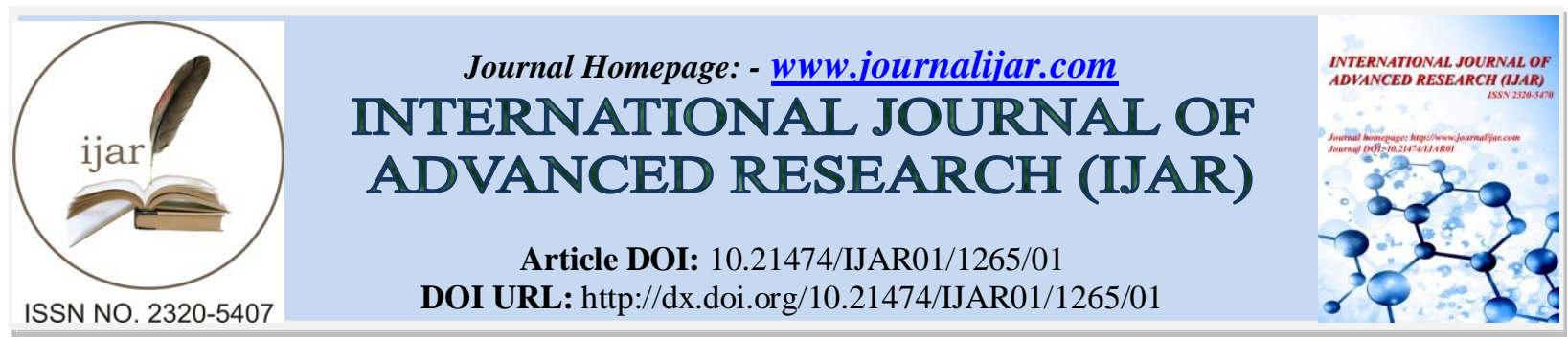

RESEARCH ARTICLE

\title{
A novel in vitro approach for enhanced production of Musa paradisiaca L. (cv. Nendran) using split sucker explants.
}

Radhika B. J, Ravichandran ${ }^{1}$ and $*$ K. Satheeshkumar ${ }^{2}$.

1. Department of Developmental Biology and Plant Biotech Lab SPK Centre for Environmental Sciences Manonmonian Sundaranar University Alwarkurichi, TamilNadu-627412.

2. Biotechnology and Bioinformatics Division Jawaharlal Nehru Tropical Botanic Garden and Research institute Palode, Thiruvananthapuram-695562.

\section{Manuscript Info}

\section{Manuscript History}

Received: 12 June 2016

Final Accepted: 16 July 2016

Published: August 2016

Key words:-

Banana cv. Nendran, Mass multiplication, Tissue culture, $\mathrm{N}^{6}$ benzyl adenine, Indole-3-acetic acid, Naphthalene acetic acid and Kinetin.

\section{Abstract}

Banana cultivar Nendran is one of the most important staple fruit crops in tropical and subtropical countries and it also plays an important role in the local economics. A novel method was developed for the large scale multiplication of plants with split segments of young sucker explants cultured in Murashige and Skoog (MS) (1962) solid medium supplemented with BAP (1.0-6.0 mg/L) .Upon comparing the number of shoot bud induction between intact sucker and split sucker explants, it was recorded that $13.70 \pm 2.49$ shoot buds were initiated in split segments against $4.20 \pm 1.13$ shoot buds in intact sucker explants in a period of four weeks. Among the split segments tested sucker split in to four symmetrical pieces produced maximum number of shoots. The shoots so emanated from both the explants were split longitudinally and sub cultured at every three week intervals to obtained $12.70 \pm 2.58$ $(2.69 \pm 0.39 \mathrm{~cm})$ shoots from intact and $48.70 \pm 5.23(4.43 \pm 0.44 \mathrm{~cm})$ shoots from split suckers respectively in the first subculture in media contain $5 \mathrm{mg} / \mathrm{L}$ BAP. Number of shoots produced from intact as well as split sucker explants was also investigated against the number of subcultures. It was also noticed that more than 9 fold increase in shoot bud formation in sub cultured shoots of split explants in lower concentration of BAP $(2.0 \mathrm{mg} / \mathrm{L})$ than the number of shoots in sub cultured shoots of intact sucker explants in media with high concentration of BAP $(5 \mathrm{mg} / \mathrm{L})$. It was also estimated that production of approximately 1540 plants was possible from a single split explant against 320 plants from the split segments of intact sucker explants after three subcultures. The shoots so obtained were rooted in media supplemented with $1.0 \mathrm{mg} / \mathrm{L}$ IBA were deflasked and established in polythene bags filled with coarse sand and soil (1:1) mixture under shade net house with adequate watering to obtained more than $98 \%$ survival. Plants obtained from different explants sources along with conventional suckers were planted and studied the field performance. The growth and yield of plants between different sources were not significantly varied from each other. The results obtain in the present investigation illustrated that split sucker explants in media augmented with low concentration of BAP $(2.0 \mathrm{mg} / \mathrm{L})$ for three subcultures leading 
to reasonable production of plants together with normal flowering would certainly help large -scale multiplication of plants with less number of explants and subculture passages.

Copy Right, IJAR, 2016,. All rights reserved.

\section{Introduction:-}

The banana and plantains (Musa spp.) belonging to the family Musaceae are one of the world's most important fruit crops. It is widely grown in the tropics and subtropics in all types of agricultural system, from small mixed subsistence gardens to large commercial cultivation. The crop serves in many developing countries as a staple food or the corner stone of the country's economy. The traditional clonal propagation method appears to be unable to supply the increasing demand for disease free and healthy planting materials of banana. The productivity of vegetative propagated banana and plantain is greatly reduced by virus disease (Lepoivre, 2000). Moreover 5 to10 suckers can be obtained per plant per year which may be of uniform size and virus free. To minimize the above mentioned problems, micro propagation could be an alternative for propagation of planting materials for banana. In this method, over a million of plants can be grown from a small or even a microscopic piece of plant tissue within a year. (Mantell et al; 1985). Moreover, the shoot multiplication cycle is very short (2-6weeks), each cycle resulting in an exponential increase in the number of shoots and plant multiplication can be continued throughout the year irrespective of the season (Razdan,1993). Propagation of banana through in vitro techniques has been reported by several workers using different explant sources and methods (Jalil et al;2003; Madhulatha et al;2004; Strosse etal; 2006; Wong et al; 2006; Venkatachalam et al; 2006,2007; Resmi and Nair,2007; Shirani et al; 2009).

In tissue culture, plant growth regulators (PGR) are the critical media components in determining the developmental pathway of the plant cells. The most established banana shoot tip culture system was achieved by using BAP as a supplement to Murashige and Skoog (MS) basal medium (Murashige and Skoog, 1962). BAP has a marked effect in stimulating the growth of axillary and adventitious buds and foliar development of shoot-tip cultures (Abeyarante and Lathiff, 2002; Buah et al; 2010). Meanwhile combinations of BAP with auxins such as indole acetic acid (IAA) or Naphthalene acetic acid (NAA) were also used for in vitro multiplication of banana. Although BAP stimulates shoot proliferation in bananas, it is also known to have mutagenic effects at high concentration producing off type plant lets (Bairu et al; 2008).

As regards yield performance, tissue cultured plants have been reported to produce 39\% higher yield than plants from sword suckers (Pradeep et al; 1992). To obtain large-scale plants at high frequency using sucker explants has been extensively used in many cultivars of banana. However, the published reports illustrated so far are usually confined to the routine procedure for mass propagation of healthy planting materials using sucker explants. Development of a protocol using split shoot tip explants of banana cv. Nendran is of prime importance.

\section{Materials and methods}

Young healthy suckers of Musa var. Nendran collected from Pathanamthitta district of Kerala during the month of June 2011 and prepared the explants for the experiments. Initially removed the leaf sheaths and trimmed the outer portion of the sucker to the size suitable for washing in a borosilicate beaker and after that they were thoroughly washed in distilled water before subjected to surface sterilization. For the purpose of surface sterilization, the explants were initially washed with $15 \%$ sterilique solution for 15 minutes and decanted the solution for further washing in sterile distilled water. Followed that the explants were dipped in $0.1 \%$ (w/v) mercuric chloride with continuous shaking for $7 \mathrm{~min}$ and washed in sterile distilled water for 2-3 times. The decontaminated suckers were prepared in such a way that the outer 2-3 more leaf sheaths were removed further to obtain the size of the sucker to $1.5-2.0 \mathrm{~cm}$ dia. at the base with shoot tip. These surface sterilized sucker explants were used for various experiments for inducing shoot buds. The intact sucker explants were used as control and in other cases, tip of the sucker cut and split the sucker into symmetrical pieces of two, four and eight pieces. Intact sucker and split explants were inoculated separately onto MS agar $(0.6 \% \mathrm{w} / \mathrm{v}$ agar) medium supplemented with different concentration and combinations of auxins (0.1-1.0 mg/L IAA) and 1.0-6.0mg/L cytokinins ( BAP and KIN). pH of the medium was adjusted to 5.8 using $0.1 \mathrm{~N} \mathrm{HCl} / \mathrm{NaOH}$ before autoclaving them at $121^{0} \mathrm{C}$ under $1.5 \mathrm{~kg} / \mathrm{cm}^{2}$ pressure for $18 \mathrm{~min}$. All 
the cultures were incubated under $16 \mathrm{~h}$ lights $\left(35 \mu \mathrm{Em}^{-2} \mathrm{~s}^{-1}\right)$ at $25 \pm 2^{0} \mathrm{C}$. For each experiment at least 10 explants were used and repeated the experiments twice.

After one week of shoot bud initiation, the intact sucker explants with single shoot was longitudinally cut into two and each piece was transferred on to MS agar medium supplemented with 3\% sucrose and varied concentration of BAP (1.0 to $6.0 \mathrm{mg} / \mathrm{l})$. Similarly the shoot buds so obtained in the split explants (4 pieces) were also cut into pieces with at least 3 shoots per piece and sub cultured on to the same media composition. Subsequent subcultures were also done in the same way at an interval of every 3 weeks that the shoot buds obtained from split as well as intact sucker explants in the first subculture were split into pieces with 3 shoot buds and inoculated in to MS solid media supplemented with 1.0 to $6.0 \mathrm{mg} / \mathrm{l} \mathrm{BAP}$.

After three subcultures, the shoots of $4-5 \mathrm{~cm}$ long were dissected out individually and inoculated on to MS solid media containing 0.5 to $5 \mathrm{mg} / \mathrm{l} \mathrm{IBA}$ for shoot elongation and rooting. After 15 to 20 days of rooting the plantlets were deflasked, washed thoroughly in running tap water to remove media remnants and planted in polythene cups filled with coarse sand and soil (1:1) mixture. The plants were kept under 50\% shade net house with timely watering. After 1 month, the plants so established in the polythene cups were sprayed with $0.1 \%$ NPK (18:18:18) and again kept them for one month under the same condition to attain the height of $30-40 \mathrm{~cm}$ with 2 to 3 additional leaves.

Randomly selected plants of 30-40 cm height with at least 4 to 5 leaves of intact sucker explants, split explants derived and equal number of conventional suckers were planted in selected fields. Before planting, the field was prepared in such a way that each pit had a size of $50 \mathrm{~cm}^{3}$ with $2 \mathrm{~m}$ distance between plants. Each pit was filled with organic compost $(3 \mathrm{~kg}$ ) consists of cow dung and dried leaves (1:2). For each experiment 20 plants were planted. The planted seedlings were watered properly and added the fertilizers $\{(100 \mathrm{gm}$ NPK (18:18:18) and 50 gm (Urea) $\}$ at an interval of one month up to 6 months. Growth in terms of height of the plant, girth of the pseudo stem and number of leaves per plant was recorded till flowering. The plants started flowering on the $8^{\text {th }}$ month of planting and the results on yield were compared between different sources of plants under field cultivation.

\section{Statistical analysis.}

Statistical analysis was performed using Microsoft Excel 2003. Data were subjected to analysis of variance (ANOVA) using a completely random design (CRD) and means were compared by DMRT LSD test at $5 \%$ significance level. The results of field performance were analyzed using student's $t$ test as described by Raghava Rao (1987).

\section{Results and discussion:-}

Results on the explants cultured in media supplemented with different concentrations of hormones either individually or in combination is presented in Table-1. Among the varied levels of hormones either individually or in combinations tested, maximum response was in media containing only BAP. Intact sucker explants cultured in media containing $5.0 \mathrm{mg} / \mathrm{l} \mathrm{BAP}$ responded, initially with a swelling and gradually the leaf sheaths split opened at the base and subsequently shoot emergence was noticed in 4 weeks. According to the concentration of BAP (1.0-6.0 $\mathrm{mg} / \mathrm{L}$ ), number of shoot bud emergence was varied and shoot bud formation was observed in media supplemented with $5.0 \mathrm{mg} / \mathrm{l} \mathrm{BAP}$ in 4 weeks. Though there was no additional shoot bud formation from the base of intact sucker explants, the existing shoot tip elongated further and developed into a shoot $(3.75 \pm 0.12 \mathrm{~cm})$ (Fig-1). Additional 2-3 new shoot bud formation was observed from the base during maintenance of the cultures for another 2 more weeks in the same medium. In the case of split explants, irrespective of the size of the split, it was observed that initially the leaf sheaths curved centripetally and small protuberances appeared at the base of the explants in 4 weeks of incubation. Number of shoot buds initiated on both intact as well as split explants was recorded. It was noticed that shoot bud initiation was maximum in split explants. Similarly, shoot initiation between split explants was also noticed and maximum number of shoot buds was obtained in sucker split into four pieces (Table-2). It was recorded that maximum number of shoot buds $(13.70 \pm 2.49)(0.92 \pm 0.30 \mathrm{~cm})$ was obtained in split segments cultured in media supplemented with 5.0.mg/l BAP in 4 weeks of culture period (Fig-2). Reduction in number of shoot bud formation from the sucker explants split into eight pieces $(3.50 \pm 1.35)$ might be owing to the loss of adequate size or number of meristematic cells during cut required for further division and differentiation into shoot buds. Based on the results obtained with the split explants, future subculture experiments were carried out with the shoots obtained from four pieces.

Influence of either BAP alone or in combination with IAA on shoot bud induction in banana is not uncommon as there are several published reports substantiate the results obtained in the present study (Jalil et al; 2003; Madhulatha et al; 2004; Abeyarante and Lathiff, 2002; Buah et al; 2010). However, higher number of shoot bud initiation in split 
explants might be due to the immediate contact of the meristemoids with the nutrient medium which was not in intact sucker explants. One week after shoot bud initiation, shoot buds on split explants were again longitudinally cut and each cluster with at least three shoot buds and also the longitudinally split shoot bud derived from intact sucker explants were sub cultured separately on to MS solid media fortified with different concentrations of BAP $(1.0-6.0 \mathrm{mg} / \mathrm{l})$ The results are presented in Table-3. Number of shoot buds multiplied in intact sucker-derived shoots varied according to the concentration of BAP and maximum number of shoots (12.75 \pm 2.58$)$ multiplied was in media supplemented with $5.0 \mathrm{mg} / \mathrm{l} \mathrm{BAP}$ in of 3 week period. Additional shoot bud formation in shoot clusters derived from split explants also found varied according to the concentration of BAP and maximum number of shoots (48.70 \pm 5.23$)$ was obtained in media containing $5.0 \mathrm{mg} / \mathrm{l} \mathrm{BAP}$.

Table 1 Response of intact and split sucker explants in media supplemented with different concentration and combinations of hormones. The results recorded after 4 weeks.

\begin{tabular}{|l|l|l|l|l|}
\hline $\begin{array}{l}\text { Plant growth regulators(PGRs } \\
\text { mg/L) }\end{array}$ & $\begin{array}{l}\text { No of shoots/split explants (shoot } \\
\text { length }(\mathrm{cm})\end{array}$ & $\begin{array}{l}\text { No of shoots/intact sucker explants } \\
(\text { Length cm) }\end{array}$ \\
\hline BAP & KIN & IAA & & \\
\hline 1.0 & - & - & $3.90 \pm 0.87(0.90 \pm 0.15)$ & $1.90 \pm 0.87(0.90 \pm 0.15)$ \\
\hline 2.0 & - & - & $8.30 \pm 1.41(0.78 \pm 0.20)$ & $3.20 \pm 1.03(0.78 \pm 0.20)$ \\
\hline 3.0 & - & - & $10.20 \pm 2.57(0.85 \pm 0.22)$ & $3.80 \pm 1.13(0.85 \pm 0.22)$ \\
\hline 4.0 & - & - & $12.00 \pm 2.16(0.98 \pm 0.24)$ & $4.00 \pm 1.19(0.98 \pm 0.24)$ \\
\hline 5.0 & - & - & $13.70 \pm 2.49(0.92 \pm 0.30)$ & $4.20 \pm 1.13(0.92 \pm 0.23)$ \\
\hline 6.0 & - & - & $11.30 \pm 1.41(0.56 \pm 0.30)$ & $3.70 \pm 1.16(0.56 \pm 0.07)$ \\
\hline- & 0.5 & 0.1 & $5.50 \pm 1.26(0.48 \pm 0.32)$ & $2.70 \pm 0.82(0.48 \pm 0.02)$ \\
\hline- & 1.0 & 0.1 & $5.30 \pm 0.94(0.53 \pm 0.30)$ & $3.30 \pm 0.67(0.79 \pm 0.08)$ \\
\hline- & 2.0 & 0.4 & $4.80 \pm 1.13(0.70 \pm 0.25)$ & $2.80 \pm 0.79(0.74 \pm 0.02)$ \\
\hline- & 3.0 & 1.0 & $4.30 \pm 1.33(0.52 \pm 0.12)$ & $2.20 \pm 0.79(0.85 \pm 0.01)$ \\
\hline- & 4.0 & 1.0 & $3.10 \pm 1.10(0.61 \pm 0.22)$ & $1.80 \pm 0.79(0.65 \pm 0.08)$ \\
\hline & 2.0 & & $4.00 \pm 1.19(0.68 \pm 0.10)$ & $2.70 \pm 0.67(0.52 \pm 0.12)$ \\
\hline & 3.0 & & $4.20 \pm 1.08(0.55 \pm 0.02)$ & $3.40 \pm 0.69(0.62 \pm 0.14)$ \\
\hline & 4.0 & & $5.30 \pm 1.24(0.54 \pm 0.18)$ & $3.60 \pm 0.52(0.72 \pm 0.20)$ \\
\hline & 5.0 & & $4.80 \pm 1.35(0.62 \pm 0.12)$ & $3.10 \pm 0.99(0.47 \pm 0.18)$ \\
\hline 1.0 & & 0.1 & $4.20 \pm 1.18(0.78 \pm 0.23)$ & $2.50 \pm 0.53(0.36 \pm 0.02)$ \\
\hline 2.0 & & 0.1 & $7.30 \pm 1.50(0.68 \pm 0.05)$ & $2.70 \pm 0.67(0.28 \pm 0.07)$ \\
\hline 3.0 & & 0.2 & $7.50 \pm 1.50(0.65 \pm 0.05)$ & $3.00 \pm 0.94(0.24 \pm 0.02)$ \\
\hline 4.0 & & 1.0 & $7.80 \pm 1.38(0.72 \pm 0.02)$ & $3.40 \pm 0.22(0.22 \pm 0.08)$ \\
\hline 5.0 & & 1.0 & $7.00 \pm 1.20(0.58 \pm 0.03)$ & $3.30 \pm 0.46(0.18 \pm 0.04)$ \\
\hline
\end{tabular}

Shoot multiplication was more in higher concentration of BAP up to $5.0 \mathrm{mg} / \mathrm{l}$. More than $5.0 \mathrm{mg} / \mathrm{l} \mathrm{BAP}$ was not found favourable for multiplication of shoots. Multiple shoot formation in sub cultured shoot clusters from split explants even in $2.0 \mathrm{mg} / \mathrm{l} \mathrm{BAP}$ was also found more than the number of multiple shoot formation in the subcultured shoots of intact sucker explants in media augmented with $5.0 \mathrm{mg} / \mathrm{l} \mathrm{BAP}$. Number of shoots multiplied in subsequent subcultures was also tested. Shoots obtained in the first sub culture were again split into clusters each with at least three shoot buds and sub cultured on to media supplemented with varied levels of BAP. It was also interesting to note that shoot multiplication was consistent in split explant-derived shoots in low concentration of BAP $(2.0 \mathrm{mg} / \mathrm{l})$, which was almost double than the number of shoots obtained in intact sucker explants - derived shoots sub cultured in media with $5.0 \mathrm{mg} / \mathrm{l} \mathrm{BAP}$ (Table-3). Whereas, shoot multiplication in shoots of intact sucker explants subcultured was consistent in media containing $5.0 \mathrm{mg} / \mathrm{l} \mathrm{BAP}$. It was estimated that production of approximately 1540 shoots was possible from a single split explant in MS solid media supplemented with $2.0 \mathrm{mg} / \mathrm{l}$ BAP in three subcultures over a period of 12 weeks against only 320 shoots in intact sucker explant-derived single split in the same period in media containing higher concentration of BAP $(5.0 \mathrm{mg} / \mathrm{l})$. The number of shoots obtained from the split sucker explants in three subcultures was approximately nine-fold more than the other system that too was possible in media containing higher concentration of BAP $(5.0 \mathrm{mg} / \mathrm{l})$.

It is generally believed that use of higher concentration of BAP $(>2.0 \mathrm{mg} / \mathrm{l})$ in banana for initiation or multiplication has not been widely accepted in commercial plant tissue culture industries as higher concentration of BAP would facilitate more sucker formation resulting less yield during cultivation . 
The shoots were rooted in media supplemented with $1.0 \mathrm{mg} / \mathrm{l}$ IBA in a period of $15-20$ days and successfully established in polythene cups filled with coarse sand and soil (1:1) mixture with proper watering under the shade net house to obtain $98 \%$ survival (Fig-3). The plants were randomly selected and planted at least 20 plants in selected area and studied the field performance of the plants compared with conventionally propagated ones. The results are presented in Table-4. The results showed no significant difference between the plants of varied sources. However, better field performance of in vitro-derived plants than conventionally propagated plants might be due to the retrospective effect of enriched nutrient milieu available to the shoots during culture period.

Table -2 Number shoots multiplied from the split explants of different sizes and intact sucker explants in MS solid media supplemented with 3\% sucrose and different concentrations of BAP. The results were recorded after 4 weeks

\begin{tabular}{|l|l|l|l|l|}
\hline BAP(mg/L) & $\begin{array}{l}\text { No. of shoots/Split } \\
(2 \text { pieces })\end{array}$ & $\begin{array}{l}\text { No. of shoots/Split } \\
(4 \text { pieces })\end{array}$ & $\begin{array}{l}\text { No. of shoots/Split } \\
(8 \text { pieces })\end{array}$ & $\begin{array}{l}\text { Intact sucker } \\
\text { explants }\end{array}$ \\
\hline 1 & $2.00 \pm 0.50$ & $3.90 \pm 0.87$ & $1.60 \pm 0.57$ & $1.90 \pm 0.87$ \\
\hline 2 & $4.50 \pm 1.10$ & $8.30 \pm 1.41$ & $2.60 \pm 0.87$ & $3.20 \pm 1.03$ \\
\hline 3 & $5.50 \pm 1.20$ & $10.20 \pm 2.57$ & $2.90 \pm 1.00$ & $3.80 \pm 1.13$ \\
\hline 4 & $6.00 \pm 1.40$ & $12.00 \pm 2.16$ & $3.50 \pm 1.35$ & $4.00 \pm 1.19$ \\
\hline 5 & $6.50 \pm 1.80$ & $13.70 \pm 2.49$ & $3.90 \pm 1.22$ & $4.20 \pm 1.13$ \\
\hline 6 & $5.40 \pm 1.65$ & $11.30 \pm 1.41$ & $3.20 \pm 1.22$ & $3.70 \pm 1.16$ \\
\hline
\end{tabular}

Table-3: Response of split as well as intact sucker explants derived shoots sub cultured (SC) in MS solid medium containing 3\% sucrose and varied levels of BAP. The results were recorded after 3 weeks.

\begin{tabular}{|l|l|l|l|l|}
\hline $\begin{array}{l}\text { BAP } \\
\mathrm{mg} / \mathrm{L}\end{array}$ & $\begin{array}{l}\text { No. of shoots/split explants } \\
\text { First SC shoot length }(\mathrm{cm})\end{array}$ & $\begin{array}{l}\text { No. of shoots/sliced shoot } \\
\text { of intact explants First } \\
(\mathrm{SC}) \text { shoot length }(\mathrm{cm})\end{array}$ & $\begin{array}{l}\text { No. of shoots/split explants } \\
\text { in second SC shoot length } \\
(\mathrm{cm})\end{array}$ & $\begin{array}{l}\text { No. of shoots/intact } \\
\text { explants-derived shoots in } \\
\text { second SC shoot length } \\
(\mathrm{cm})\end{array}$ \\
\hline 1.0 & $7.80 \pm 1.25(2.35 \pm 0.40)$ & $5.10 \pm 0.12(4.62 \pm 0.39)$ & $20.50 \pm 1.31(3.37 \pm 0.28)$ & $12.70 \pm 1.88(3.40 \pm 0.55)$ \\
\hline 2.0 & $27.50 \pm 2.42(3.87 \pm 0.53)$ & $6.20 \pm 0.95(4.45 \pm 0.28)$ & $68.80 \pm 1.85(3.41 \pm 0.41)$ & $15.50 \pm 1.33(2.57 \pm 0.43)$ \\
\hline 3.0 & $30.50 \pm 3.56(4.59 \pm 0.63)$ & $7.12 \pm 0.31(3.46 \pm 0.70)$ & $76.20 \pm 1.65(3.92 \pm 0.52)$ & $17.80 \pm 1.53(3.89 \pm 0.60)$ \\
\hline 4.0 & $39.40 \pm 4.27(4.45 \pm 0.67)$ & $10.31 \pm 1.65(3.56 \pm 0.31)$ & $98.50 \pm 2.79(4.28 \pm 0.42)$ & $25.70 \pm 1.44(3.43 \pm 0.41)$ \\
\hline 5.0 & $48.70 \pm 5.23(4.43 \pm 0.44)$ & $12.75 \pm 2.58(2.69 \pm 0.39)$ & $121.80 \pm 1.52(4.09 \pm 0.57)$ & $31.70 \pm 1.23(3.25 \pm 0.29)$ \\
\hline 6.0 & $28.60 \pm .2 .4(4.33 \pm 0.38)$ & $10.89 \pm 1.78(3.24 \pm 0.55)$ & $73.30 \pm 1.20(4.06 \pm 0.74)$ & $27.20 \pm 1.20(4.04 \pm 0.26)$ \\
\hline
\end{tabular}

Table-4. Field Performance of Plants from different sources cultivated in three selected fields under uniform condition with proper watering and fertilizer application. For each study ten plants were cultivated. The data recorded during transplantation of plants up to harvest stage.

\begin{tabular}{|l|l|l|l|}
\hline & $\begin{array}{l}\text { Intact Sucker explant- } \\
\text { derived plants }\end{array}$ & $\begin{array}{l}\text { Split explant-derived } \\
\text { plants }\end{array}$ & $\begin{array}{l}\text { Conventionally } \\
\text { propagated plants }\end{array}$ \\
\hline Plant height $(\mathrm{cm})$ & $185.30 \pm 8.23$ & $180.10 \pm 8.32$ & $169.10 \pm 6.57$ \\
\hline Stem girth $(\mathrm{cm})$ & $57.34 \pm 4.10$ & $55.63 \pm 3.12$ & $52.07 \pm 4.14$ \\
\hline No. of leaves & $24.20 \pm 3.55$ & $23.10 \pm 3.83$ & $22.40 \pm 2.56$ \\
\hline Bunch Fresh weight $(\mathrm{Kg})$ & $12.90 \pm 2.29$ & $12.25 \pm 2.30$ & $9.75 \pm 1.33$ \\
\hline No of hangs & $5.00 \pm 0.72$ & $4.87 \pm 0.50$ & $4.07 \pm 0.90$ \\
\hline No of fingers/bunch & $49.10 \pm 4.07$ & $45.35 \pm 3.08$ & $38.87 \pm 3.09$ \\
\hline No. of Additional suckers & $4.20 \pm 0.28$ & $2.80 \pm 0.12$ & $5.00 \pm 0.85$ \\
\hline
\end{tabular}




\section{Figures:-}

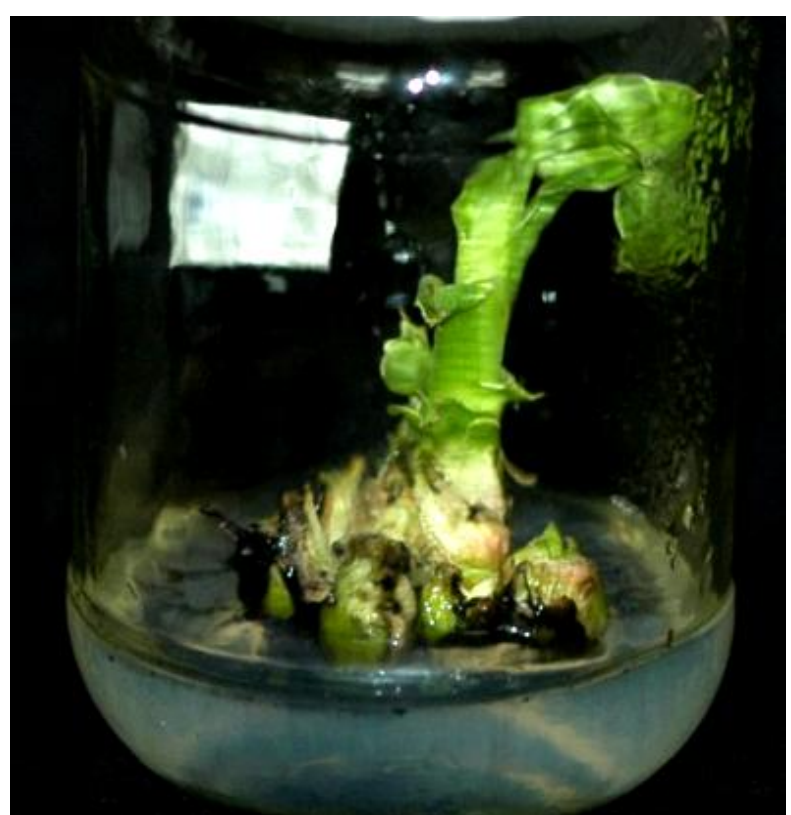

Fig-1 shoot emanated from intact

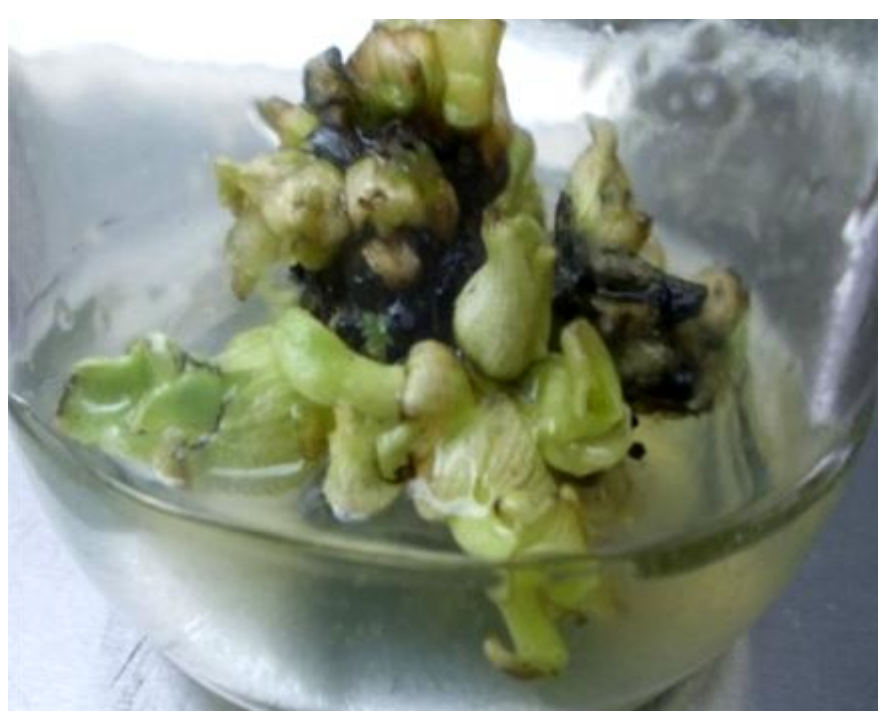

Fig-2 Multiple shoot formation in split explants Sucker explants after 4 weeks. Cultured after 4 weeks 


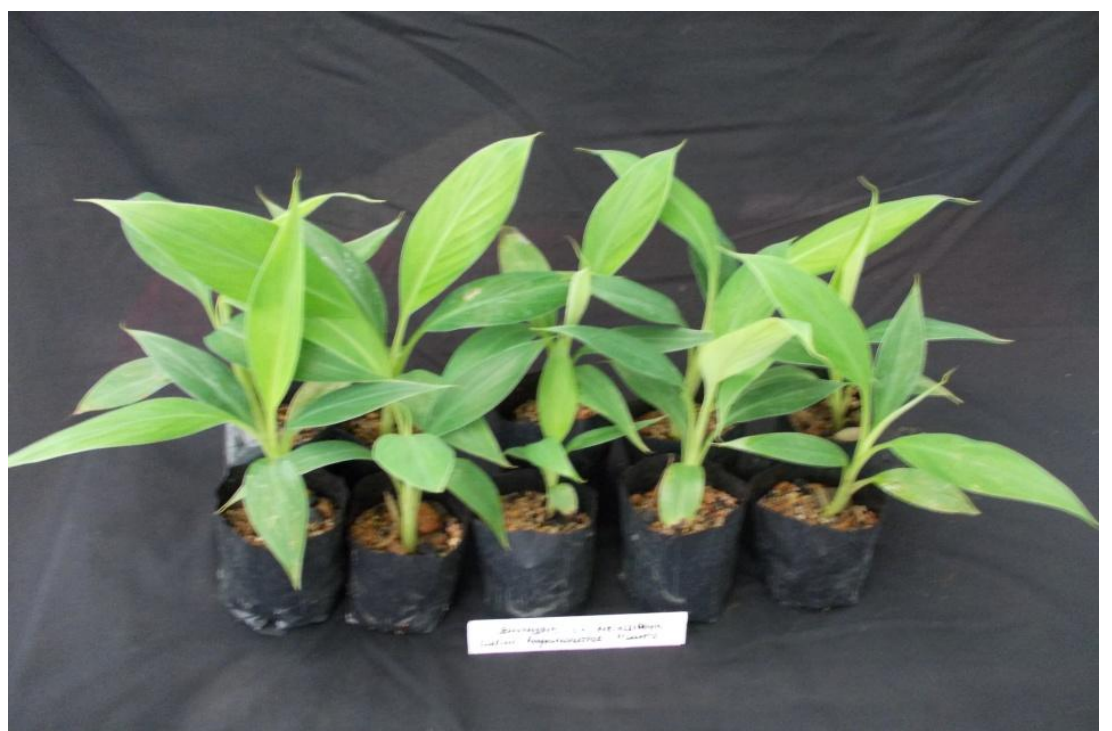

Fig-3 In vitro- derived plants established in polythene bags after 30 days of primary hardening

\section{Conclusion:-}

The overall results obtained in the present investigation suggest that the sucker explants split into four pieces can be opted as a novel system for commercial production of selected banana plants as the system is better than intact sucker explants in terms of number of shoot proliferation in media supplemented with lower concentration of BAP $(2.0 \mathrm{mg} / \mathrm{L})$. The results on short subculture period of 12 weeks for mass production plus 2 weeks for rooting of plants in media containing $1.0 \mathrm{mg} / \mathrm{L}$ IBA using split explants against the subculture period of 22 weeks and 2 weeks for rooting in plants derived from intact sucker explants also signify the relevance of the system for future use. Besides, maintaining the same yield potential of the split explant-derived plants under field cultivation also suggested the worth of the proposed system for further use in commercial production.

\section{Acknowledgement:-}

The authors thank the Director, Jawaharlal Nehru Tropical Botanic Garden and Research Institute (JNTBGRI), Palode, Thiruvananthapuram, Kerala for providing necessary facilities to undertake the research work. We also thank Manonmaniam Sundaranar University, Thirunelveli, India for the approval of Ph. D programme.

\section{References:-}

1. Abeyaratne WM, Lathiff MA (2002). In-vitro propagation of 'Rathambala' (Musa AAA) and the occurrence of phenotypic variations in the pseudo stem. Annals of the Sri Lanka Department of Agriculture (LKA), 4:191 197.

2. Arinaitwe G, Rubaihayo PR, Magambo MJS (2000). Proliferation rate effects of cytokinins on banana (Musa spp.) cultivars. Sci. Horticult. 86:13-21.

3. Bairu MW, Strik WA, Dolezal K, Staden JV (2008). The role of topolins in micropropagation and somaclonal variation of banana cultivars 'Williams' and Grand Naine (Musa spp.AAA). Plant Cell Tissue Organ Cult. 95: 373-379.

4. Buah JN, Danso E, Taah KJ, Abole EA, Bediako EA, Asiedu J, Baidoo R (2010). The effects of different concentration cytokinins on the in vitro multiplication of plantain (Musa spp.) Biotechnology 9(3): 343-347.

5. Jalil M, Khalid N, Othman RY (2003). Plant regeneration from embryogenic suspension cultures of Musa accuminata cv. Mas (AA). Plant Cell Tissue Organ Cult.75:209-214.

6. Lepoivre, p. (2000). Banana in vitro regeneration: Virus eradication. Laboratory of plant pathology, University of Gembloux, Belgium, p.22.

7. Madhulatha P, Anbalagan M Jayachandran S, Sakthivel N (2004). Influence of liquid pulse treatment with growth regulators on in vtro propagation of banana (Musa spp. AAA). Plant Cell Tissue Organ Cult.76:189192.

8. Mantell, SH; Mathews J.A and McKee RA (1985). Principles of Biotechnology. Blackwell scientific PubI., Oxford, UK p. 269. 
9. Ma SS, Shi CR (1972). In vitro formation of adventitious buds in banana shoot apex following decapitation. J. Hort, Sci., 18:135-142.

10. Murashige T, Skoog F (1962). A revised medium for rapid growth and bioassays with tobacco tissue culture. Physiol. Plant 15: 473-497.

11. Pradeep KP, Zachariah G. Estelittanad S, Suma A. (1992). Field performance of banana tissue culture plants of variety Nendran (Musa AAB). South Indian Hon. 40(1): 1-4.

12. Raghava Rao, D. (1987). Statistical techniques in Agricultural and Biological research. Oxford and IBH Publ. Co., New Delhi, pp. 85.

13. Razdan, MK. (1993). An Introduction to Plant Tissue Culture. Oxford and IBH publishing Co. Pvt. Ltd., New Delhi, $342 \mathrm{p}$.

14. Resmi L, Nair AS (2007). Plantlet production from the male inflorescence tips of Musa accuminata cultivars from South India. Plant Cell Tissue Organ Cult. 88: 333-338.

15. Shirani S, Mahdavi F, Maziah M (2009). Morphological abnormality among regenerated shoots of banana and plantain (Musa spp.) after in vitro multiplication with TDZ and BAP from exiced shoot tips. Afr. J. Biotechnol. 8(21): 5755-5761.

16. Subramaniam S, Rathinam X, Poobathy R, Sinniah U (2008). In vitro production of multiple bud clumps (Mbcs) from Cavendish banana cultivar, Brasilian (AAA) American-Eurasian J. Sustainable Agric. 2(3): 300307.

17. Strosse H, Schoofs H, Pains B, Andre E, Reyniers K, Swennen R (2006). Development of emryogenic cell suspension from shoot meristamatic tissue in banana and plantains (Musa spp.). Plant Sci.170: 104-112.

18. Vuylsteke D, De Langhe EA (1985). Feasibility of in vitro propagation of bananas and plantains. Trop. Agric. (Trinidad). 62: 323-328.

19. Venkatachalam L, Sreedhar RV, Bhagyalakshmi N (2007). Micro propagation in banana using high levels of cytokinins does not involve any genetic changes as revealed by RAPD and ISSR markers. Plant growth regul. 51: 192-205.

20. Venkatachalam L, Thimmaraju R Sreedhar RV, Bhagyalakshmi N (2006). Direct shoot and cormlet regeneration from leaf explants of 'Silk" banana (AAB). In vitro Cell. Dev. Biol. Plant 42: 262-269.

21. Wong WC, Jalil M, Ong-Abdullah M, Othman RY, Khalid N (2006). Enhancement of banana plant regeneration by incorporating a liquid based embryo development medium for embryogenic cell suspension. J. Horticult. Sci. Biotechnol. 81: 385-390.

22. Zaffari GR, Kerbauy GB, Kraus JE, Romano EC (2000). Hormonal and histological studies related to in vitro banana bud formation. Plant Cell Tissue Organ Cult. 63 (3): 187-192. 